\section{SOI: 1.1/TAS DOI: $10.15863 / \mathrm{TAS}$ International Scientific Journal Theoretical \& Applied Science}

p-ISSN: 2308-4944 (print)

e-ISSN: 2409-0085 (online)

Year: 2015

Issue: 09

Volume: 29

Published: 30.09 .2015

http://T-Science.org
Konstantin Ivanovich Kurpayanidi

$\mathrm{PhD}$ in Economics,

Professor of the Russian Academy of Natural Sciences,

Fergana Polytechnic Institute,

Uzbekistan

w7777@mail.ru

SECTION 31. Economic research, finance,

innovation, risk management.

\title{
IMPLEMENTATION OF INNOVATION AND INVESTMENT DECISIONS IN TODAY'S TRANSNATIONAL CORPORATIONS
}

Abstract: In this paper we study the introduction of innovative and investment decisions in today's transnational corporations. Based on an analysis of major activities of transnational corporations, the authors provide suggestions for improvement of the mechanism of implementation of innovative solutions into production.

Key words: innovation, multinational, innovative solution.

Language: English

Citation: Kurpayanidi KI (2015) IMPLEMENTATION OF INNOVATION AND INVESTMENT DECISIONS IN TODAY'S TRANSNATIONAL CORPORATIONS. ISJ Theoretical \& Applied Science 09 (29): 137-143.
Soi: http://s-o-i.org/1.1/TAS-09-29-27
Doi: crossef http://dx.doi.org/10.15863/TAS.2015.09.29.27

Problems of financing of innovation in the global economy are solved by three main actors: the state, venture capital firms and modern corporation. Since the topic of the dissertation research is due to the study of mechanisms of realization of innovations by large companies, the aspects of public and venture participation, we consider only the part that overlaps with corporate innovation processes. The financial power of the modern corporation allow them to successfully implement innovation. Financial risks for innovation-driven corporation is lower than for venture capital investors, as a result of a careful selection of innovative projects, "routinization" of the innovation process in the framework of corporate planning, having its own R \& D base and innovation potential. The quest for innovation can be explained as follows: innovative products are the basis of longterm competitiveness and overall production a significant share, in addition, the Corporation acquired the patents, the effect of which is substantially higher than the cost of their purchase. You should also take into account the effect of the dynamic capabilities of these companies, when a new product is obtained as a result of combining several seemingly unrelated ideas [1].

With the general trend of modern corporations to strengthen the role of innovation in the long-term development strategies, there is a national specificity. European corporations, realizing the concept of open innovation, integrate their research and development department with universities, research centers at the locations of highly qualified personnel, which is followed and American companies. Integration is not only in terms of collaboration on promising innovative projects of scientists, researchers and engineers, but also in terms of co-financing $R \& D$ [2].

The last 50 years developing to developed countries and is gaining popularity in countries with economies in transition, the creation of venture enterprises. Create ventures enables corporations to locate innovation risks, do not spray resources and encourage innovation, which has an indirect relationship to the corporate strategies [3]. Venture financing innovation in large corporations it is expedient at the location of the parent company, with the exception of this phenomenon as the "Silicon Valley", which attracts many foreign corporation level infrastructure favorable "cloud" the conditions for the creation and dissemination of new ideas, knowledge and technology that allows you to create competitive products and solutions.

In developed European countries have long been innovation, manufacturing of high-tech products is a priority. At the same time at different stages of the development life cycle, development and manufacture of new products or technologies developed strategic manufacturing and / or marketing alliances [4].

The European countries with the 1990s to develop and implement tools to support and stimulate innovative entrepreneurship. The system of measures 
and tools stand out, both direct and indirect forms tax breaks, preferential government loans, depreciation policy). Specificity of innovative business in Japan is that the government finances socially significant, as basic research, allocations for science comes to universities and public research centers. This Japanese investment largely directed to the development of the economy as a whole, while Western corporations increasingly restricted the effectiveness of innovative solutions within the firm [5]. It is worth noting that the countries of South-East Asia used a wide range of incentives to attract investment in innovative companies, increasing funding for research and development, increasing the share of private investment in $\mathrm{R} \& \mathrm{D}$, the development of their own research centers [6]. The
РИНЦ (Russia) $=\mathbf{0 . 1 7 9}$

$\mathrm{ESJI}(\mathrm{KZ}) \quad=\mathbf{1 . 0 4 2}$

SJIF $($ Morocco $)=\mathbf{2 . 0 3 1}$ global crisis of 2008 was the fundamental test of the intentions of the market leaders in innovation to invest in research and development, which are the basis of their strategic plans. Top management of advanced western corporations for years argued that investments in innovation - competitive necessity, not a form of temporary investments, which can be stopped as soon as the hard times will come. On the other hand, some analysts have speculated that the company still cut their budgets for research and development under the pressure of the crisis. However, this did not happen. As the post-crisis studies have Western corporations do not reduce investment in innovation, even in a tough recession (Table 1).

Expenditures on innovation and development (R \& D) [7].

Table 1

\begin{tabular}{|l|c|c|}
\hline & Cut spending on R \& D, \% & Increased spending on R \& D, \% \\
\hline The company's net profit & 17,2 & 52 \\
\hline The company had loss & 14,3 & 16,5 \\
\hline Net income increased & 8,4 & 26,7 \\
\hline Net income decreased & 22,2 & 42,7 \\
\hline
\end{tabular}

The reasons are as follows:

1. Innovation became a central element of corporate strategy. Reduction of innovative investments in the fierce competition in the business of high technology is akin to unilateral disarmament in the war. Corporations can not afford to stop the continuous process of development and adoption of new products.
2. Companies in most sectors of the economy, as a rule, guided by the development of product cycles that extend for many years. If they are suppliers, they are often already signed a contract for the supply of customers following a new model; if they sell directly to consumers, the lack of innovation cycle can mean to be derived from the game completely.

Table 2

Top 20 Innovative Companies list Global Innovation 1000 [8].

\begin{tabular}{|c|c|c|c|c|c|c|}
\hline \multicolumn{2}{|l|}{ Years } & \multirow[t]{2}{*}{ Company } & \multicolumn{2}{|c|}{ Spendings on R\&D } & \multirow[t]{2}{*}{ Head-quarters } & \multirow[t]{2}{*}{ Sphere } \\
\hline 2014 & 2013 & & $\begin{array}{l}2014 \\
\text { bilion. } \\
\text { USD }\end{array}$ & $\begin{array}{l}\text { Change } \\
\text { from } \\
2013, \%\end{array}$ & & \\
\hline 1 & 1 & Volkswagen & 13.5 & 18.4 & Germany & Automotive \\
\hline 2 & 2 & Samsung & 13.4 & 28.8 & South Korea & $\begin{array}{ll}\text { Computing } & \text { and } \\
\text { electronics } & \end{array}$ \\
\hline 3 & 4 & Intel & 10.6 & 5.0 & United States & $\begin{array}{ll}\text { Computing } & \text { and } \\
\text { electronics }\end{array}$ \\
\hline 4 & 5 & Microsoft & 10.4 & 6.0 & United States & Software and internet \\
\hline 5 & 3 & Roche Holding & 10.0 & -2.0 & Switzerland & Healthcare \\
\hline 6 & 7 & Novartis & 9.9 & 6.4 & Switzerland & Healthcare \\
\hline 7 & 6 & Toyota & 9.1 & -7.2 & Japan & Automotive \\
\hline 8 & 10 & Johnon\&Johnson & 8.2 & 6.4 & United States & Healthcare \\
\hline 9 & 12 & Google & 8.0 & 17.6 & United States & Software and internet \\
\hline 10 & 8 & Merck & 7.5 & -8.6 & United States & Healthcare \\
\hline 11 & 11 & General Motors & 7.2 & -2.8 & United States & Automotive \\
\hline 12 & 14 & Daimler & 7.0 & 6.0 & Germany & Automotive \\
\hline 13 & 9 & Pfizer & 6.7 & -15.2 & United States & Healthcare \\
\hline 14 & - & Amazon & 6.6 & 11,2 & United States & Software and internet \\
\hline
\end{tabular}




\section{Impact Factor:}

\begin{tabular}{|c|c|c|}
\hline ISRA (India) & $=1.344$ & SIS (USA) \\
\hline ISI (Dubai, UAE & 0.82 & РИНЦ $($ Russia $)=\mathbf{0 . 1 7 9}$ \\
\hline IF (Australia) & $=0.356$ & ESJI $(\mathrm{KZ}) \quad=\mathbf{1 . 0 4 2}$ \\
\hline & $=1.500$ & SJIF $($ Morocco $)=\mathbf{2 . 0 3 1}$ \\
\hline
\end{tabular}

\begin{tabular}{|l|l|l|l|l|l|l|}
\hline 15 & - & Ford & 6.4 & 7,3 & United States & Automotive \\
\hline 16 & 15 & Sanofi-Aventis & 6.3 & 0,0 & France & Healthcare \\
\hline 17 & 13 & Honda & 6.3 & -7.4 & Japan & Automotive \\
\hline 18 & 16 & IBM & 6.2 & -1.6 & United States & $\begin{array}{l}\text { Computing } \\
\text { electronics }\end{array}$ \\
\hline 19 & 17 & GlaxoMithKline & 6.1 & -3.2 & United Kingdom & Healthcare \\
\hline 20 & - & Cisco & 5.9 & 9,3 & United States & $\begin{array}{l}\text { Computing and } \\
\text { electronics }\end{array}$ \\
\hline & & & 165.3 & 3.95 & & \\
\hline
\end{tabular}

3. Many corporations view the economic downturn as an opportunity to create a competitive advantage over their competitors - especially in the case of lack of funding $\mathrm{R} \& \mathrm{D}$ weak players. If stronger companies will be able to maintain the pace of innovation, they are able to quickly increase its market share and get the proper innnovation rent, counting on the future pace of economic revival. It can be concluded that the corporation continues to expand investment innovation, have a decent margin of safety and financial stability. This means that their corporate economics and management possess specific qualities of effective combination of production and innovation processes.
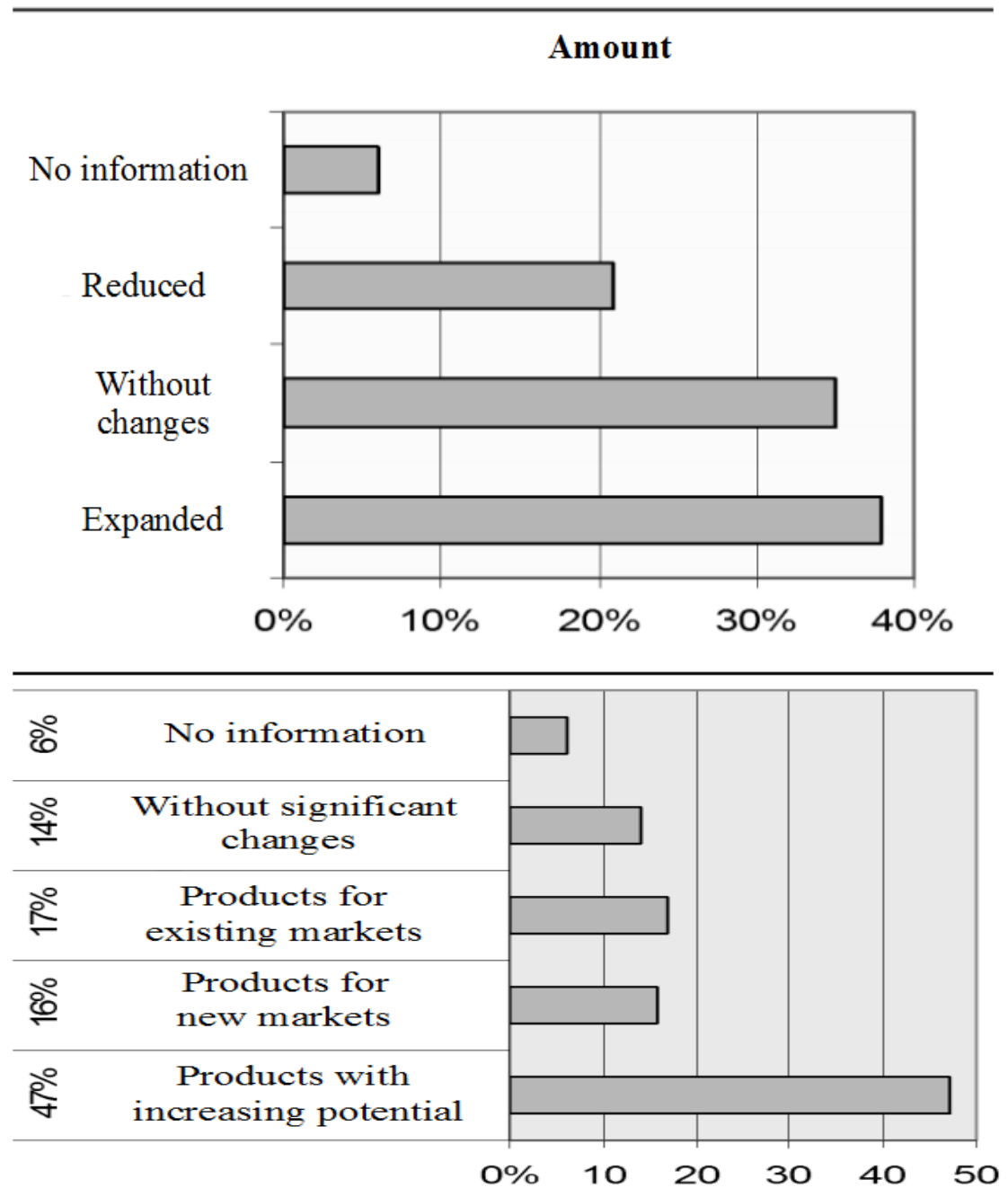

Changes in the innovation portfolio

Figure 1 - Resizing an innovative portfolio.

More than two-thirds of the companies included in the list of Global Innovation 1000, maintain or increase the level of investment in research and development. It found no correlation between the financial losses and a reduction in spending on $\mathrm{R} \&$ D. The study showed that almost $\%$ of the companies are expanding or retain innovative portfolio, and about $2 / 3$ to focus on increasing production capacity 
and products for new markets (Fig. 1) [9]. Computers and electronics industry keeps the first place for the costs of innovation among industries, spending 149 billion. Dollars, which is $28 \%$ of the total investment in research and development. During the reporting period from October 1, 2013 to September 30, 2014, the net profit of the Group reached 5.5 billion. Euros. Total sectors profit rose $26 \%$ to $\$ 7.3$ billion. Euros compared to last year's 5.8 billion. Euros thanks to an improved performance in the field of industry and infrastructure and cities. The portfolio of new orders "Siemens AG" was 78.4 billion. Euro. The company's turnover - 71.9 billion. Euro.

"We have achieved those results, which have stated in the beginning of the 2014 fiscal year, and made substantial progress in strengthening our portfolio. "Vision 2020" gives us a clear understanding of how we will develop further, "- said President and CEO" Siemens AG "Joe Kezer [10].

Corporations included in the Top-1000 "Global Innovation" certainly not been immune to its effects. Total sales rose by 6.5 percent to 15 trillion. dollars much less than the $10 \%$ growth recorded between 2006 and 2007. Thus, the intensity of investment innovation - as a percentage of sales - remained unchanged at $3.6 \%$. The analysis shows that the amount of money that companies spend on R \& D, does not depend on the activities of all corporations in general. Such dynamics can be traced last 5 years[11]. The software sector and the Internet sees the crisis as a new opportunity. Among them are Intel. The main goal of Intel Corporation is to be unique (mostly) chip manufacturer semiconductors and platforms for the global tech economy. The main products include microprocessors, chipsets and flash memory[12].

In 2009 Intel started a deep crisis in the history of the company. Intel came out of it with innovative products and technology to strengthen the market. Implementing a global strategy to compete in the relevant market segments, Intel uses a competitive advantage in the design and manufacture of integrated circuits, attracting and working with the financial resources of software development, the advantages of global presence and brand awareness[13].

Key areas of strategy [14]:

acustomer focus - the development of nextgeneration products based on the needs and expectations of customers. In turn, these products make it possible to design and develop new form factors and models.

- Architecture and platforms - creating energyefficient solutions for high-performance computers and other devices. Development of multi-core microprocessors.

- Industrial and technological leadership - a strategy of microprocessors with improved performance to synchronize the introduction of new microarchitecture improvements in production technology with microprocessors. Entering a new microarchitecture approximately every two years and create the next generation of manufacturing technology of microprocessors in the interim. This schedule allows us to develop and market new products to present quickly, without waiting for the next generation of manufacturing technology. Such a rate of technological development Intel calls "TickTock".

- Strategic investments - investments in companies that will contribute to the achievement of strategic objectives and mainly aimed at companies and initiatives to stimulate growth in the technological ("digital") economy, creating new business opportunities for Intel, so expanding world markets for the products. Current investments, primarily focused in the following areas: promotion of flash memory, the introduction of mobile wireless devices, the promotion of the concepts of "digital home" and "digital enterprise", creation of high communicational infrastructure, the development of next-generation manufacturing process of microprocessors.

- external business environment to stimulate innovation, promote industrial standards, which will lead to the emergence of innovation and improvement of technology for the benefit of users.

Volume of products.

Table 3

Volume

\begin{tabular}{|c|c|c|c|c|c|}
\hline & & FY 2014 & FY 2013 & Actual & $\begin{array}{l}\% \text { Change } \\
\text { Comparable }\end{array}$ \\
\hline \multicolumn{6}{|c|}{ Continuing operations } \\
\hline Orders & in millions of $€$ & 78,350 & 79,755 & (2)\% & $1 \%$ \\
\hline Revenue & in millions of $€$ & 71,920 & 73,445 & (2)\% & $1 \%$ \\
\hline
\end{tabular}

ISPC Modern research and development,

Philadelphia, USA 


\section{Impact Factor:}

ESJI (KZ)

SJIF $($ Morocco $)=\mathbf{2 . 0 3 1}$

It can be clearly seen from the table above that orders in the company amount to 79.755 million euros in 2013, in the meantime, supposedly owing to decreased demand, this figure was marginally lower 78.350 million euros. Similarly to orders revenue has alike trend, however, in this case the decrease was slightly more noticeable. Also interesting is the fact that comparable change in both indicators, excluding currency translation and portfolio effects, was $1 \%$.

Overall, it is evident from the table provided that all the indicators in 2014 had at least $25 \%$ increase as opposed to the year before. Profit in total sectors increased from 5.842 to 7.335 million euros, from 2013 to 2014 (26\%). This increase was almost proportional to the rise in percents of revenue 7.9 and 10 percent, in 2013 and 2014 respectively.

The table supplied gives information related to the customers and innovation. Evident is the fact that research and development is becoming increasingly important in the company as the time passes. Namely, in 20144.1 billion euros were spent on research development, while, a year earlier slightly lower 4.0 billions.

Profitability and capital efficiency.

Table 4

\section{I | Profitability and Capital efficiency}

\begin{tabular}{|c|c|c|c|c|}
\hline & & FY 2014 & FY 2013 & $\%$ Change \\
\hline \multicolumn{5}{|l|}{ Total Sectors } \\
\hline Total Sectors profit & in millions of $€$ & 7,335 & 5,842 & $26 \%$ \\
\hline in \% of revenue (Total Sectors) & in $\%$ & 10.0 & 7.9 & \\
\hline \multicolumn{5}{|l|}{ Continuing operations } \\
\hline Income from continuing operations & in millions of $€$ & 5,400 & 4,179 & $29 \%$ \\
\hline Basic earnings per share & in $€$ & 6.24 & 4.81 & $30 \%$ \\
\hline Return on capital employed (ROCE) & in $\%$ & 17.2 & 13.7 & \\
\hline \multicolumn{5}{|c|}{ Continuing and discontinued operations } \\
\hline Net income & in millions of $€$ & 5,507 & 4,409 & $25 \%$ \\
\hline Basic earnings per share & in $€$ & 6.37 & 5.08 & $25 \%$ \\
\hline Return on capital employed (ROCE) & in $\%$ & 17.3 & 13.5 & \\
\hline
\end{tabular}

Also, the statement mentioned above is perfectly solidified by the employees working in R\&D, approximately 29 thousand people were employed for working in this. Unsurprisingly, patents and patent first filing had almost identical trend. Siemens - a global leader in electronics and electrical engineering. Concern operates in the areas of industry and energy, as well as in health care.

\section{Customers and innovation.}

Table 5

\section{| | Customers and Innovation}

\begin{tabular}{|c|c|c|c|}
\hline & & FY 2014 & FY 2013 \\
\hline Revenue generated by the Environmental Portfolio & in billions of $€$ & 33.0 & 31.9 \\
\hline in \% of revenue from continuing operations & in $\%$ & 46 & 43 \\
\hline Research and development expenses & in billions of $€$ & 4.1 & 4.0 \\
\hline in $\%$ of revenue from continuing operations & in $\%$ & 5.7 & 5.5 \\
\hline Research and development employees & in thousands & 28.8 & 28.1 \\
\hline Inventions & in thousands & 8.6 & 8.3 \\
\hline Patent first filings & in thousands & 4.3 & 4.0 \\
\hline
\end{tabular}

More than 160 years Siemens stands for technical progress, innovation, quality, reliability and international cooperation. Highly qualified personnel - that's the basis of success Siemens, whose skills,

ISPC Modern research and development, 


\section{Impact Factor:}

\begin{tabular}{|c|c|c|}
\hline ISRA (India) & $=1.344$ & SIS (USA) \\
\hline & & РИНЦ (Russia) = \\
\hline tralia) & $=0.3$ & $\mathbf{E S J I}(\mathrm{KZ}) \quad=\mathbf{1 . 0 4 2}$ \\
\hline JIF & $=1.500$ & SJIF $($ Morocco $)=\mathbf{2 . 0 3}$ \\
\hline
\end{tabular}

abilities, knowledge is one of the elements of core competencies of the corporation. To date, the development and introduction of innovative products, the development corporation has been around 400000 employees. In Russia, Belarus and Central Asia, there are more than 3,500 people [15]. Over 160 years of research and development activities are closely linked to the Siemens business strategy. The purpose of the corporation to become leaders in all areas of business from existing and new technologies.

Siemens has registered about 58,000 patents worldwide, compared with 56,000 in 2009.

Indicators of internal research and development.

Table 6

\begin{tabular}{|l|l|l|l|}
\hline & $\mathbf{2 0 1 0}$ & $\mathbf{2 0 0 9}$ & $\mathbf{2 0 0 8}$ \\
\hline Inventions, pieces & 8800 & 7700 & 8200 \\
\hline Patent applications, pieces & 4300 & 4200 & 5000 \\
\hline
\end{tabular}

$\mathrm{R} \& \mathrm{D}$ intensity is estimated as the ratio of $\mathrm{R} \&$ $\mathrm{D}$ expenditures and revenues it is for period of 2008 2010 about 5\%, which is evident from the Table. 6 . Also it is interesting to note that as the time passes the number of inventions are not increasing in a stable trend, likewise is the trend of patnet applications.

\section{R \& D Siemens (compiled from corporate report).}

Table 7

\begin{tabular}{|l|l|l|l|l|l|l|}
\hline & $\mathbf{2 0 1 4}$ & $\mathbf{2 0 1 3}$ & $\mathbf{2 0 1 2}$ & $\mathbf{2 0 1 0}$ & $\mathbf{2 0 0 9}$ & $\mathbf{2 0 0 8}$ \\
\hline $\begin{array}{l}\text { The number of employees engaged in the research } \\
\text { department }\end{array}$ & 28800 & 29000 & 29600 & 30100 & 31800 & 32200 \\
\hline R \& D costs, mln. Euro & 55500 & 5400 & 5100 & 3846 & 3900 & 3784 \\
\hline The percentage of total revenue invested in R \& D & $5,7 \%$ & $5,5 \%$ & $5,3 \%$ & $5,1 \%$ & $5,1 \%$ & $4,9 \%$ \\
\hline
\end{tabular}

Source: Corporate of Report Siemens Corporation http://www.siemens.com/investor/en/index.htm

Table 8

Aggregated analytical balance of Siemens, mln. euros.

\begin{tabular}{|c|c|c|}
\hline & $\begin{array}{l}\text { At the beginning of } \\
\text { the year }\end{array}$ & At the end of the year \\
\hline \multicolumn{3}{|l|}{ Assets } \\
\hline 1. Cash and short-term investments & 14108 & 10159 \\
\hline 2. Accounts receivable (switches on other current assets) & 16229 & 15640 \\
\hline 3. Reserves and costs & 15740 & 14741 \\
\hline Total current assets (working capital) & 49648 & 43634 \\
\hline 4. Non-current assets & 53178 & 51292 \\
\hline Total assets (property) & 102827 & 94926 \\
\hline \multicolumn{3}{|l|}{ Liabilities } \\
\hline 1. Accounts payable and other short-term liabilities & 38175 & 35788 \\
\hline 2. Short-term borrowings & 2416 & 698 \\
\hline Total short-term debt capital (short-term liabilities) & 40591 & 36486 \\
\hline 3. Long-term debt capital (long-term liabilities) & 26538 & 25654 \\
\hline 4. Equity capital & 29096 & 27287 \\
\hline Total liabilities (assets) & 102827 & 94926 \\
\hline
\end{tabular}

Source: Corporate Report corporation Siemens http://www.siemens.com/investor/en/index.htm additional calculations author

Cooperation with universities and other research institutions have made important contributions to strengthening the innovation Siemens. The main objective of such projects is the use of the potential for joint research and development, as well as the development and expansion of the network of universities and institutes with which Siemens engages in order to attract highly qualified young professionals. Data analysis is proof that innovation is the main element of the modern corporation. 
Thus, the analysis of world practice has shown that the most important role in the implementation of innovation (share of $\mathrm{R} \& \mathrm{D}$ funding over 60\%) belongs to business and big business. Corporations are more attractive place to work for researchers and wages and working conditions, which naturally led to an increase in the number of employees in research and development. At the moment, the number of such employees of corporations is more than $50 \%$ of the total number of personnel engaged in $\mathrm{R} \& \mathrm{D}$ in Western countries.

As the analysis (from companies such as Intel, Siemens, Samsung, Japanese corporations - corporate reports [17]) modern corporations are investing in research and development of not less than $5 \%$ of annual sales.

\section{References:}

1. Kurpayanidi K (2015) Innovation component of the business environment as a factor enhancing economic growth // Economics. Moscow. - 2015.-№1. ISSN 2410-289X. - pp. 6-9.

2. Chesbro G (2007) Otkrytye innovacii / Per. s angl. V.N. Egorova - M.: Pokolenie, 2007. $-336 \mathrm{p}$.

3. Pereverzeva MN, Maljavina AV, Popov SA (2009) Venchurnye mehanizmy finansirovanija innovacionnyh proektov //Menedzhment v Rossii i za rubezhom, №3, 2009. pp. 22-28.

4. Patrik J, Jashin VG (2009) Innovacionnaja dejatel'nost' v Germanii // Problemy teorii i praktiki upravlenija, №1, 2009. pp. 62-70.

5. Kotter DP (2004) Liderstvo Macusity. M.: Al'pina biznes buks, 2004.

6. Aoki M (1995) Firma v japonskoj jekonomike / per. s angl. - Spb.: Lenizdat, 1995. - $431 \mathrm{p}$.

7. (2013) The global innovation 1000 Navigating the Digital Future [Electronic resource]. $\quad-\quad$ Available: http://www.booz.com/media/file/BoozCo_2 013-Global-Innovation-1000-Study-

Navigating-the-Digital-Future.pdf (Accessed: 16.08.2015).

8. (2015) Available: http://www.strategyand.pwc.com/global/ho me/what-we-think/innovation1000/topinnovators-spenders

(Accessed: 16.08.2015)

9. (2013) The global innovation 1000 Navigating the Digital Future [Jelektronnyj resurs]. Available: URL:http://www.booz.com/media/file/Booz Co_2013-Global-Innovation-1000-StudyNavigating-the-Digital-Future.pdf (Accessed: 16.08.2015).
10. (2015) «Simens AG» podvel itogi 2014 finansovogo goda. -[Electronic resource]. Available:

http://w3.siemens.ru/press_office/pr_archiv e/40728.html ( Accessed: 16.08.2015).

11. (2015) R\&D Scoreboard: Despite crisis, top EU firms continue to invest in innovation [Electronic resource]. - Available: http://europa.eu/rapid/press-release IP-121324 en.htm (Accessed: 16.08.2015).

12. (2009) Intel corporation form $10-\mathrm{k}$ for the fiscal year ended december 26, 2009 [Electronic resource]. - Available: http://www.intc.com/intelAR2009/common/ pdfs/Intel_2009_Form_10-K.pdf (Accessed: 16.08.2015).

13. Chesbro G (2007) Otkrytye innovacii / Per. s angl. V.N. Egorova -M.: Pokolenie, 2007. $-336 \mathrm{p}$.

14. (2009) Intel corporation form $10-\mathrm{k}$ for the fiscal year ended december 26, 2009 [Electronic resource]. - Available: http://www.intc.com/intelAR2009/common/ pdfs/Intel_2009_Form_10-K.pdf

(Accessed: 16.08.2015).

15. (2013) Siemens Annual report 2013 [Electronic resource]. - Available: http://www.siemens.com/investor/en/index. htm (Accessed: 16.08.2015).

16. (2013) Siemens Annual report 2013 [Electronic resource]. - Available: http://www.siemens.com/investor/en/index. htm (Accessed: 16.08.2015)

17. (2015) R\&D Scoreboard: Despite crisis, top EU firms continue to invest in innovation [Electronic resource]. - Available: http://europa.eu/rapid/press-release_IP-121324_en.htm (Accessed: 16.08.2015). 